\title{
Epidemiological and molecular study of Rotavirus infection among human and animal in Karbala and Basrah provinces
}

\author{
F.K. Aldawmy ${ }^{\circledR}$, H.T. Thwiny ${ }^{\circledR}$ and H.M. Abo Almaali ${ }^{(i}$ \\ ${ }^{1}$ Department of Basic Science, College of Pharmacy, University of Alzahraa, Karbala, ${ }^{2}$ Department of Microbiology, \\ College of Veterinary Medicine, University of Basrah, Basrah, ${ }^{3}$ Department of Basic Science, College of Pharmacy, \\ University of Karbala, Karbala, Iraq
}

\section{Article information \\ Article history: \\ Received April 22, 2020 \\ Accepted August 27, 2020 \\ Available online March 15, 2021}

\section{Keywords:}

Reverse Transcription

ICT

Calves

\section{Correspondence:}

F.K. Aldawmy

faten.a@uokerbala.edu.iq

\begin{abstract}
This study was aimed to determine the prevalence of rotaviruses in Karbala and Basrah provinces, the genetic reassortment of human and animal rotavirus strains and the novel strains. Rotaviruses were detected by Immunochromatography Test (ICT) then the positive samples were tested by reverse transcription PCR (RT-PCR) using specific primers to VP7 gene, this gene is responsible for VP7 antigen which is responsible for stimulation the immune system to produce neutralizing antibodies. The VP7 gene was implemented in rotavirus vaccine of Iraqi immunization program. The RT PCR results showed that 56.3\% (27/48) of samples positive in children under five years of age in Karbala province while Basrah province revealed 58.5\% (31/53) positive samples in children whereas samples taken from calves revealed $43.1 \%(22 / 51)$ and $45.5 \%$ (25/55) positive samples in Karbala and Basrah provinces respectively. The sequencing of human and animal samples revealed that there was genetic reassortment between human and animal strains while in comparing with international strains there was closely related with Indian and Pakistani human strains. Necessarily for further bioinformatics studies are needed to study the genetic alterations with viral proteins analysis of rotavirus.
\end{abstract}

DOI: 10.33899/ijvs.2020.126997.1428, (C2021, College of Veterinary Medicine, University of Mosul.

This is an open access article under the CC BY 4.0 license (http://creativecommons.org/licenses/by/4.0/).

\section{Introduction}

Reoviridae family contains Rotavirus is a non-enveloped double stranded RNA (dsRNA) virus that according phylogenetic analysis resolved into 8 types (RVA to RVH) analysis (1). The rotavirus genome consists of $11 \mathrm{dsRNA}$ segments which code for the six structural (VP1-VP4, VP6, VP7), VP4 and VP7 responsible for viral attachment proteins and neutralization antigens (2). VP4 cleavage into two fragments VP8 and VP5 when a activated by proteolytic at the tip of the VP5 attached in circular form with VP8 and VP6 trimers make attach with both VP7 and VP4 trimers on the outer shell (3) while VP2 consist of 120 particles of the viral protein (4) RNA polymerase (RdRp) affected on the central shell around the eleven segments of viral genome of dsRNA also the viral RNA, the covering enzyme and VP3 and VP1 then conical cylinders concerning the replication multiplexes have been formed by resolving the genomic RNA segments (5). Internationally, G4P 8 strain, G3P 8 strain, G2P 4 strain, G1P 8 strain and G9P 8 strain these rotavirus strains are considered as the greatest infective source in human infections. most dominant with $37.7 \%$ are G1P 8 strains (6). Rotavirus A was detected as one of the highest members and widely studied as one of causes diarrheal infection in infants and young children with life threatening diarrhea internationally. Group A rotavirus (RVA) is responsible for acute dehydration diarrhea in humans and animals. RVA shows wide range diversity and a variety of human strains share genetic and antigenic features with animal origin RVA strains. RVA shows wide range diversity and a variety of human strains share genetic and antigenic features with animal origin RVA strains (7). 
Recently facts depending on detection methods as serological or direct virus detection confirmed that animal also susceptible to rotavirus infection and the incidence of rearrangements in the genome of RVA within diverse species were caused by circulation of RVA in domestic animals, depending on environmental conditions in studied region (8). In humans the primary impartial is that, immunization is prompted in children suffering from severe infection this immunization gives active immunity when antibody from mother were decreased in age range between fourth- sixth months. In 2019 many countries have been deduced this vaccine in national immunization program. Active immunity induced by immunization is prompted to preceding during the first few years of children lives when the risk of severe infections (i.e., hospitalization and deaths) is the greatest after the reduction of maternal antibody level by the age of 4-6 months (5). Rotaviruses infect livestock particularly calves causing economic loss due to highly cost of treatment and highly rates of mortality and morbidity, Rotavirus have ability to genetic alteration with Rotaviruses from human origin, these Rotaviruses are a potential reservoir for genetic exchange with human rotaviruses (9). There is indication that animal rotaviruses can infect humans, either by direct transference of the virus or by sharing in one or several RNA segments to reassortment with human strains (10). The infection and replication of Rotavirus occurs in mature, non-dividing enterocytes in the middle and tip of the villi and in enteroendocrine cells in the small intestine (11), signifying that these cell types explicit factors that are responsible for efficient infection and replication (12).

\section{Materials and methods}

\section{Pediatric stool samples}

A whole of 200 of diarrheal stool samples were collected from hospitalized children during the period from November 2018 to August 2019. Majority of these samples were collected from children under 5 years of age who were hospitalized with suspected rotavirus gastroenteritis. A total of 100 samples were admitted from children in pediatrics hospital of Karbala province and the other 100 samples from Maternity and children hospital in Basrah province. All samples were collected and analyzed under aseptic conditions.

\section{Bovine fecal samples}

In winter season of 2018-2019 with cold weather, about 134 and 179 fecal samples were collected from domestic diarrheic calves in Karbala and Basrah provinces respectively, with rang of age from three months to two years. Stimulation of rectum was done for collection of feces in disposable plastic container then sent with sterilized circumstances to the laboratory.

\section{Rotavirus identification}

The samples were tested for Rotavirus antigen by using Immunochromatography Test (ICT) LumiQuick, AdenoRotavirus Antigen Comb Test Card Immunochromatography, according to the manufacturer's instructions.

\section{RNA extraction}

FavroPrep ${ }^{\mathrm{TM}}$ for isolation of viral nucleic acid from supernatant stool samples were used. It based on mini spin column (silica matrix) for the isolation of viral RNA, according to the manufacturer's instructions.

\section{Reverse transcription}

Bioneer Accupower ${ }^{\circledR}$ RocketScript ${ }^{\mathrm{TM}} \mathrm{RT}$ PreMix is a complete system for the efficient synthesis of first strand cDNA from RNA templates and combines all the reagents necessary for successful cDNA synthesis in a convenient individually aliquot and lyophilized in single-tube, two-step format. RTase, which is an RNA-dependent DNA polymerase that is used in cDNA synthesis with long RNA template. During cDNA generation random hexamer primers were used to exposure to all regions of the RNA when cDNA was produced having different lengths of cDNA. The first strand of cDNA can be directly used as a template in PCR.

\section{cDNA Synthesis}

Reagents and samples were brought at room temperature before starting with the reaction, $10 \mu 1$ of RNA were added to the reaction tube and the final volume is completed up to $20 \mu \mathrm{l}$ with RNase free water and mixed gently and spundown by microcentrifuge. The reaction tube then placed in the thermal cycler programmed (table 1). These generated cDNA pool having different lengths of cDNA. Synthesized cDNA is immediately used as template for PCR, or kept at $20^{\circ} \mathrm{C}$ for farther use.

Table 1: Reverse transcription reaction thermal profile

\begin{tabular}{lcc}
\hline No & Temperature & Time \\
\hline 1 & $37^{\circ} \mathrm{C}$ & $10 \mathrm{~min}$ \\
2 & $42^{\circ} \mathrm{C}$ & $30 \mathrm{~min}$ \\
3 & $95^{\circ} \mathrm{C}$ & $5 \mathrm{~min}$ \\
4 & 4 & Hold \\
\hline
\end{tabular}

\section{PCR amplification of $v p 7$ Gene}

At room temperature the master mix contents were taken before usage and on a separate biohazard safety cabinet the PCR master mix was done. For each PCR reaction within single pre-mixed ready to use PCR reaction tube containing Taq DNA polymerase, dNTPs, $\mathrm{MgCl} 2$ and reaction buffers from Bioneer company (Korea), adding $3 \mu \mathrm{l}$ from forward primer, GGCTTTAAAAGAGAGAATTTCCGTCTGG (10 $\mathrm{pmols} / \mu \mathrm{l})$ and $3 \mu \mathrm{l}$ from reverse primer, GGTCACATCATACAATTCT (13). (10 pmols/ $\mu \mathrm{l})$ for $v p 7$ 
gene.in each reaction tube seven microliter of tubes were then adequate mixing of the components of the reaction by micro centrifuge.

\section{DNA sequencing}

Sequencing of samples was done by Macrogen company (Korea). and sequencing result were viewed and compared with reference DNA sequence using Blast software.

\section{Statistical analysis}

The data were analyzed $(\mathrm{P}<0.05)$ by chi square test using SPSS statistical software. for checking all values and through tab trial to investigate significant comparison between viral infection percentages in different studying markers of population study.

\section{Results}

\section{Prevalence of Rotavirus in human stool samples}

The results showed 48 samples out of 100 were positive for rotavirus infection from pediatric teaching hospital in Karbala province. While in Basrah province 53 out of 100 samples were positive in diarrheic children, (Figure 1, Table 2).

Table 2: The results of Human Rotavirus Detection in Karbala and Basrah provinces by Imunochromotography Test (ICT)

\begin{tabular}{lccc}
\hline Province & Total samples & Positive & Negative \\
\hline Karbala & 100 & $48(48 \%)$ & $52(52 \%)$ \\
Basrah & 100 & $53(53 \%)$ & $47(47 \%)$ \\
\hline Total & 200 & $101(50.5 \%)$ & $99(49.5 \%)$ \\
\hline $\mathrm{X} 2=0.5, \mathrm{df}=1, \mathrm{P}=0.479$. & &
\end{tabular}

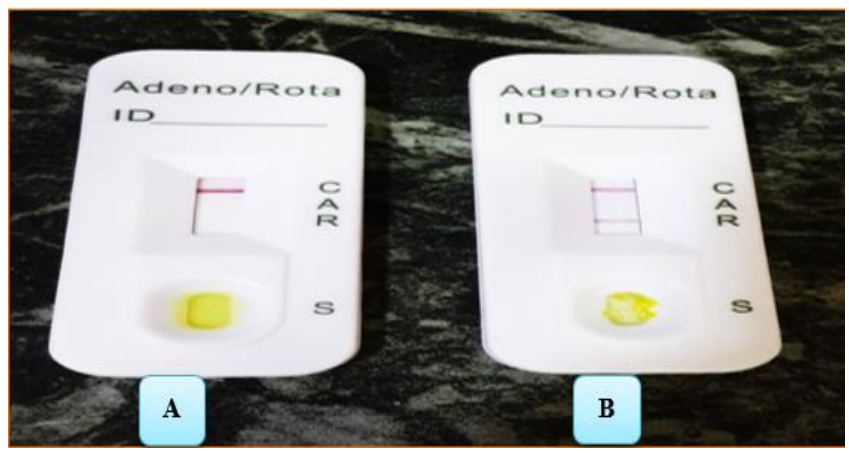

Figure 1: Imunochromotography test showed negative result with rotavirus (A), positive result (B).

\section{Prevalence of Rotavirus in bovine fecal samples.}

All the 313 diarrheic fecal samples were screened for group A rotavirus using immunochromatography test (ICT). Overall, 51 and 55 samples had detectable rotavirus infection from Karbala and Basrah provinces respectively (Table 3).
Table 3: The result of bovine rotavirus detected in Karbala province and Basrah province by imunochromatography test (ICT)

\begin{tabular}{lccc}
\hline Province & Total samples & Positive & Negative \\
\hline Karbala & 134 & $51(38.1 \%)$ & $83(61.9 \%)$ \\
Basrah & 179 & $55(30.7 \%)$ & $124(69.3 \%)$ \\
\hline Total & 313 & $106(33.9 \%)$ & $207(66.1 \%)$ \\
\hline $\mathrm{X} 2=1.84, \mathrm{df}=1, \mathrm{P}=0.174$. & &
\end{tabular}

\section{Detection of Rotavirus by RT-PCR: Diarrheic human samples}

In order to Immunochromatography assay results, conventional PCR was carried out to detection the gene of outer layer VP7 1062bp. The extracted RNA transcribed to cDNA, these samples were amplified with primers for the

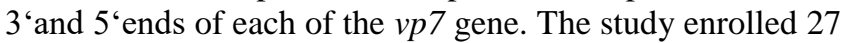
samples out of 48 Rotavirus positive samples (by an Immunochromatography assay) in Karbala province in table 3. While in Basrah province RT-PCR demonstrated 31 samples from 53 Rotavirus positive samples (by an Immunochromatography test) table 3 . The amplicon size of $v p 7$ gene was $1062 \mathrm{bp}$ as shown in figure 2 , table 4 .

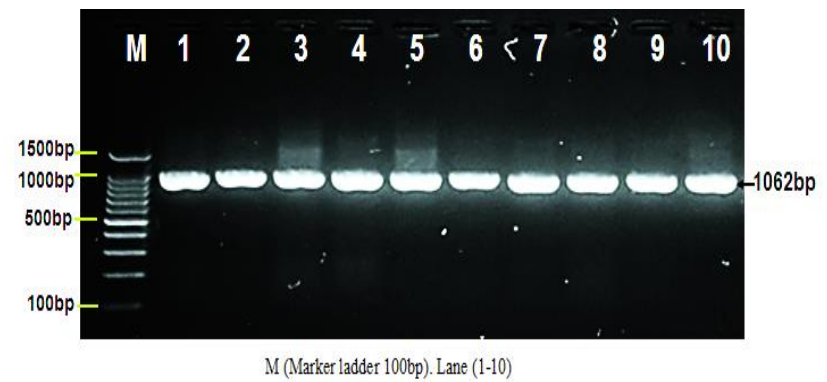

Figure 2: RT-PCR product at 1062bp analysis for VP7 gene in Rotavirus from human with 100 bp DNA ladder.

Table 4: The results of human Rotavirus detected in Karbala and Basrah provinces by (RT-PCR)

\begin{tabular}{lccc}
\hline Province & Total samples & Positive & Negative \\
\hline Karbala & 48 & $27(56.3 \%)$ & $21(43.7 \%)$ \\
Basrah & 53 & $31(58.5 \%)$ & $22(41.5 \%)$ \\
\hline Total & 101 & $58(57.4 \%)$ & $43(42.6 \%)$ \\
\hline$X 2=0.05$, &
\end{tabular}

$\mathrm{X} 2=0.05, \mathrm{df}=1, \mathrm{P}=0.819$.

\section{Diarrheic animal 's samples}

All bovine fecal samples gave positive results for Imunochromatographic assay were confirmed by RT-PCR. In present investigation, out of 51 only $22(43.1 \%)$ positive samples screened for the presence of group A rotavirus specific vp7 1062bp genes in Karbala province, nearly similar result was conducted in Basrah province 25 (45.5\%) were positive (Table 5), (Figure 3). In the present study, screening of bovine fecal samples was done to know the 
prevalence of rotavirus infection and confirms the circulation of group A rotavirus in Karbala and Basrah provinces that allows to understand mechanisms that may effect on interspecies transmission route of rotavirus which play an important contributes to the diversity of human RVA strains as a zoonotic virus.

Table 5: Animal Rotavirus detection in Karbala and Basrah provinces by Polymerase Chain Reaction (PCR)

\begin{tabular}{cccc}
\hline Province & Total samples & Positive & Negative \\
\hline Karbala & 51 & $22(43.1 \%)$ & $29(56.9 \%)$ \\
Basrah & 55 & $25(45.5 \%)$ & $30(54.5 \%)$ \\
\hline Total & 106 & $47(44.3 \%)$ & $59(55.7 \%)$ \\
\hline $\mathrm{X} 2=0.05, \mathrm{df}=1, \mathrm{P}=0.809$. & &
\end{tabular}

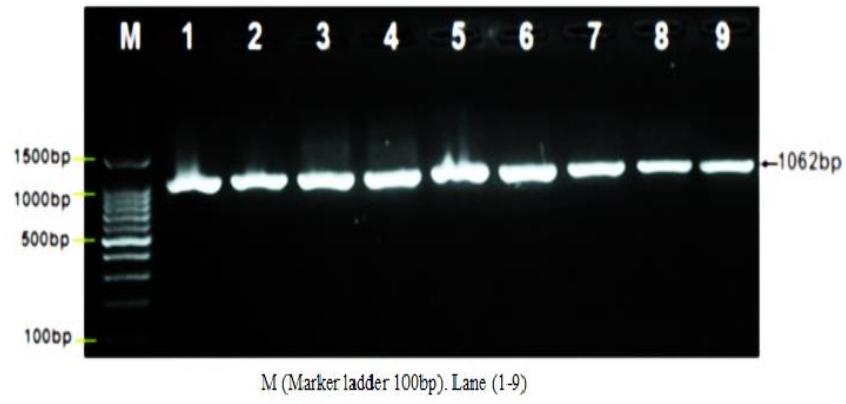

Figure 3: RT-PCR product at 1062bp analysis for VP7 gene in Rotavirus from animal with 1500 bp DNA ladder.

\section{Sequence of DNA detected}

The accession number of local Iraq's strain in present study demonstrated in (Table 6).

Table 6: Clinical sample from human amplified using Rotavirus $v p 7$ gene specific primers

\begin{tabular}{cccc}
\hline No & $\begin{array}{c}\text { Type of } \\
\text { gene }\end{array}$ & $\begin{array}{c}\text { Current study strain } \\
\text { (GeneBank accession No.) }\end{array}$ & Source \\
\hline 1 & Vp7 & MK801760.1 & Human \\
\hline
\end{tabular}

(Note) In current study the sequencing was don for human sample only to use for further analysis.

\section{DNA sequence alignment}

Using Blast software for all local samples of vp7derived from diarrheic human samples derived nucleotide sequences were aligned for matching with the reference database (GenBank) revealing the local human samples reveled (100\% identity) completely match for vp7 human sample with reference vp7gen GenBank sequence accession ID: K681838 as shown in figure 4, phylogenetic tree shows closely related with human origin strains from Pakistan and India (Figure 5).

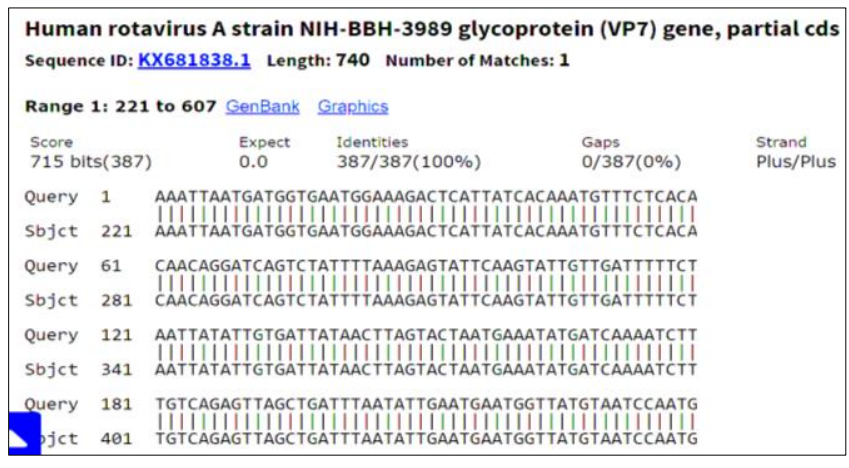

Figure 4: GenBank database alignment of $v p 7$ gen DNA sequence from local human sample showing $100 \%$ match with match with reference human Rotavirus, using Blast.

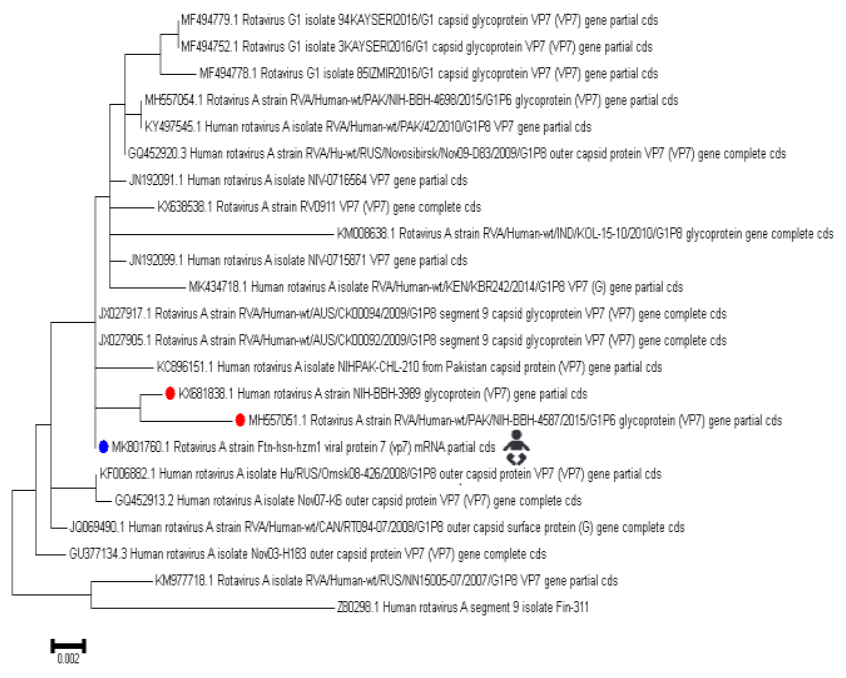

Figure 5: $v p 7$ gene segment phylogeny for local sequence indicated in blue point and other closely corresponding international sequence indicated in red point Molecular phylogenetic analysis was done using Maximum Likelihood Method.

\section{Discussion}

Prevalence of Rotavirus in human stool samples by Imunochromotography Test (ICT)

The most common causes of pediatric gastroenteritis are Rotaviruses in worldwide, mainly in children under 5 years (2). Even though (14) assumed the improvement of infection may be not lead to diarrheal deaths with remains significant of diarrheal disease. The previous studies on Rotavirus detection were most frequently associated with diarrheic children under 5 years in Iraqi children this agree with locally studies by (15). The features of the children whose stool samples revealed Rotavirus infection results by rapid Immunochromatographic test (ICT) showed 48\% and 53\% in Karbala and Basrah provinces respectively (Table 2), in 
accordance with our results, (16) who collected the samples from five Iraqi provinces (Babil, Karbala, Missan, Qadissiya, and Wasit) found a similar prevalence (47.2\%), was positive by using (IC) test. Another studies conducted in Basrah city/Iraq hospitalized children (17) found a lesser prevalence of viruses (31\%) suffering from Rotavirus by Immunochromatographic test (ICT) test as a simple and easy to read with limited equipment needed. The international scenario of rotavirus prevalence exhibited through (18) who used conventional methods (eg, IC test and ELISA test) for Rotavirus detection and detected $24 \%$ of children under five years with Rotavirus infection.

\section{Rotavirus prevalence in bovine fecal samples by Imunochromotography Test (ICT)}

The current study, screening of bovine fecal samples was concluded to identify the occurrence of rotavirus infection and checks the circulation of group A rotavirus in middle and south area of Iraq for drawing the map of calves diarrheal that allows for application of effective and targeted continuous strain surveillance in licensure area to understand mechanisms that may effect on interspecies transmission mechanism of rotavirus which play an important participates to the diversity of strains RVA from human origin as a zoonotic virus. The present results demonstrated (38\%) and (30\%) of Rotavirus infection in Karbala and Basrah provinces respectively (Table 3 ). This result was compatible with study of (19) found there is no significant variances between Male and female (37.5\%, 40\% respectively) were seen diseased. While (20) found range prevalence or Rotavirus A by using chromatographic immunoassay (Monoclonal antibodies) to capture the attendance of rotavirus virus antigen with $71 \%$ (85 of 119 samples) were highest positive in Wasit province, but the lowest positive was in Dyala province 15\% (4 of 26 samples) in middle provinces regions of Iraq from cattle and buffalo calf with acute diarrhea.

\section{Prevalence of rotavirus in human stool samples by Polymerase Chain Reaction (PCR)}

Viral gene was detected by using PCR technique which has a vital role to detect genes in vary strains furthermore bypassing primers which mismatch connection with template. Therefor recognizing $v p 7$ gene (glycoprotein) according to its function in infection and pathogenesis as outer capsid protein for neutralization antibody and enter to host cell in replication cycle $(21)$. While $(22,23)$ showed RTPCR less efficiency than RT-qPCR for amplification in comparison with +ve and -ve control. The present study was designed to explore the role of group A rotavirus as causative agents of diarrhea by using PCR assay as more sensitive technique, in Basrah and Karbala provinces. The prevalence of genotype specificity that assumed in further than one host may be attained as a good alternative to prediction the host species origin. Actually the image is more complicated as many host species may have a diversity of genotypes, and at the present time or in prospectively in a far time appear the dramatic of associated host species that may release a unique strain rotaviruses patterns according to credited genomic diversity in numerous hosts species (24).There is an profusion of molecular epidemiological data on the opportunity out of both usual and unusual VP7 (glycoprotein, G-genotype) protein determined by Reverse transcription PCR amplification (RT-PCR) in world. The present study by using PCR technique for amplification of $v p 7$ gene (by rotavirus specific primer) from human and animal with desired amplicon size is designed to detect the occurrence of Rotavirus and its molecular description to identify the genotypes which are distributed between human and animal populations, Rotavirus was detected in $57 \%$ in human samples (Table 4), therefore, the results of present study were somewhat consistent with many Iraq's studies for example in percent $51.98 \%$ in Middle Iraq was conducted by (25). In other hand Iraqi Kurdistan, exposed lesser incidence $37 \%$ of infected children with gastroenteritis were septic with rotavirus $(26,27)$ showed there is no significant statistical difference in regarding geographies only male more than female, medical features, kind of treatment and course of illness (except period of onset). And about 47.4\% of acute gastroenteritis cases of diarrheic sample with no significant statistical difference between rotavirus and other sources of gastroenteritis regarding demographic features (except for gender, more in males), clinical features, and type of treatment and course of disease (except time of onset). The proportion in present study was lower than that $40.5 \%$ (81/200) and 24.6\% (34/138) observed in Basrah children $(28,29)$ respectively and $(30)$ showed $42.45 \%$ in infant in the Mid region of Iraq. Other study found $40.3 \%$ among acute diarrheal children aged less than five years in Baghdad province (31).

\section{Prevalence of Rotavirus in bovine fecal samples by Polymerase Chain Reaction (PCR)}

The present study on animal fecal samples was undertaken to express specific genotypes of RVAs circulating among calves for their eventual control in different parts of Iraq and association of Rotavirus with clinical cases of diarrhea was traditional in bovine population of Karbala and Basrah region was confirmed by RT-PCR. Discovering the revolving genotypes in susceptible animal population from different geographical area of Iraq is a vital to understand the virus evolution, interspecies transmission, especially when we are in a phase of introduction the prophylactic vaccine. In view of which, the present study was started to check the survival and circulating genotypes in calves RVAs isolates from high elevation areas of the state have a prevalence of $43.1 \%$ and 45.5\% in Karbala and Basrah provinces respectively was noticed (Table 5). This result higher than studies of (20) showed (17\%) because of the Iraqi hot climate and molecular 
lab difficulties in middle and south area of Iraq. Other study also showed lower result than our study it was $15.5 \%$ of diarrheic calves associated with rotavirus infection as a serious cause of neonatal calf diarrhea and the highest rate of infection was recorded in the diarrheic calves in 8-15 days of age in Mosul city, Iraq (32). The present study compatible with study in Missan 48\% (12 of 25 samples) and the lowest was in AlQadissiya $28 \%$ (7 of 25 samples) (16). When compared to other studies the percentage of rotaviruspositive specimen of our study also compatible with studies reported by many investigators such as $49.4 \%$ in Iran (33) while in Babylon about $(23 \%)$ of Rotavirus infection was recorded in calves (34). The vital role of molecular detection in this study compatible with (35) and (36) who used also molecular diagnosis and genetic relationship in virus.

\section{DNA sequence analysis}

The present study significant the similarity of genetic features between human and animal that applied to further studies are needed to understand the dynamics of rotavirus transmission, cycle, and to identify alternative management practices to minimize the risk of Rotavirus. also there is numerous suggestions previously confirmed that bovine rotaviruses (BRVs) have talent to cross the host species barrier and circulate among neonates with creating zoonotic transmission then can infect human. However, the predominance of these strains can vary obviously in different settings and from one year to the next. The sequencing after employed reverse transcription PCR amplification is a marginal apparatus for detection genotypes of rotavirus, all amplified these genes were admitted for DNA sequencing analysis in order to validate them then aligned together with local and international sequence from GenBank using Clustal W software program in order to identify relationship between the local and international strains that aids to confirmation that human rotavirus strain is a zoonotic origin may infect animal with same strain and to permit the mutation in detected samples that may reduce vaccine efficient then all these reliable evidence give us lucid idea about surveillance strain in era and if an employed vaccine have an effectiveness for illness protection against Rotavirus infection according to its neutralized outer antigen $v p 7$ with ID: MK801760.1 (Table 6).

\section{Phylogenetic tree analysis}

Phylogenetic tree and comparison analyses were achieved to conclude the relationship between most recurrently identified rotavirus, the close relation of local sample sequences to each other as it is clustered in one branch away from other international derived sequences. The present study showed the genetic diversity of local strain from human have ID: MK801760.1 with closely related with MH557051.1 and KX681838.1 from India and Pakistan respectively (Figure 5). According to this relationships of local strains the genotypic distribution of rotavirus strains displays temporal and geographical fluctuations, and knowledge of the molecular epidemiology of rotaviruses is important for the development of vaccines and diagnostic reagents (37). However, still studies are required to characterize the RV isolates recovered from the area at genomic level to realize the evolution of this evolving rotavirus isolates which are dominating in human-bovine population in Iraq. Nevertheless, present study of vp7 local strains from archived samples in a district area of middle and west Iraq co-circulation of different genetic variants within the defined time-frame was noted. DNA sequence analysis was performed in this study, elucidating genetic variability with possible genome re-assortment with no hint of vaccine derived changes in VP7 gene were observed in human, animal and vaccine during the study period, which confirmed that Rotavirus as a Zoonotic pathogen with ability to retransmitted between human and animal therefore it is important to update of vaccine according to novel strains derived by human animal assortment also more studied are needed to understand Rotavirus protein's specially proteins interfere with vaccine preparation in order to design a suitable vaccine covering the most variant strains.

\section{Conclusion}

The similarity between current human and animal strains have been indicate the ability of recombination between human and animal, our rotavirus strains similar to Indian and Pakistani strains.

\section{Acknowledgment}

The authors wish to thank College of Veterinary Medicine, University of Basrah and College of Pharmacy, University of Karbala, for financially supporting this work, laboratory of both colleges.

\section{Conflict of interest}

Authors declare no conflict of interests of the manuscript.

\section{References}

1. Matthijnssens J, Ranst MV. Genotype constellation and evolution of group A rotaviruses infecting humans. Curr Opin Virol. 2012;2(4):426433. DOI: $10.1016 /$ j.coviro.2012.04.007

2. Desselberger. Rotaviruses. 2014;22(190):75-96. DOI: 10.1016/j.virusres.2014.06.016

3. Settembre EC, Chen JZ, Dormitzer PR, Grigorieff N, Harrison SC. Atomic model of an infectious rotavirus particle. EMBO J. 2011;30:408-16. DOI: 10.1038/emboj.2010.322

4. McClain B, Settembre E, Temple BR, Bellamy AR, Harrison SC. Xray crystal structure of the rotavirus inner capsid particle at $3.8^{\circ} \mathrm{A}$ resolution. J Mol Biol. 2010;3973(2):587-599. DOI: 10.1016/j.jmb.2010.01.055

5. Jayaram H, Estes MK, Prasad BV. Emerging themes in rotavirus cell entry, genome organization, transcription and replication. Virus Res. 2004;4(1):67-81. DOI: 10.1016/j.virusres.2003.12.007 
6. Bányai K, Laszlo B, Duque J, Duque J, Duncan Steele A, Anthony E, Nelson S, Gentsch J, Parashar U. Systematic review of regional and temporal trends in global rotavirus strain diversity in the pre rotavirus vaccine era: insights for understanding the impact of rotavirus vaccination programs. Vaccine. 2012;30(1):122-30. DOI: 10.1016/j.vaccine.2011.09.111

7. Dóró R, Farkas SL Martella V, Bányai K. Zoonotic transmission of rotavirus: surveillance and control. Exp Rev Therap. 2015;13(11):1337- 50. DOI: 10.1586/14787210.

8. Barros BCV, Chagas EN, Bezerra LW, Ribeiro LG, Júnior JWBD, Pereira D, Junior ETP, Silva JR, Bezerra DAM, Bandeira RS, Pinheiro HS, Guerra SF, Guimarães RJPS, Mascarenhas JP. Rotavirus A in wild and domestic animals from areas with environmental degradation in the Brazilian Amazon. PLoS One. 2019;14(1):e0211311. DOI: 10.1371/journal.pone.0211311

9. Ask LS. The introduction of rotavirus vaccine in Sweden - setting the scene and short term outcomes [Master's thesis]. Stockholm: Department of Medicine, Solna Division of Clinical Epidemiology Karolinska Institutet, Stockholm, Sweden; 2019.

10. Martella V, Bányai K, Matthijnssens J, Buonavoglia C and Ciarlet M. Zoonotic aspects of rotaviruses. Vet Microbiol. 2010;140(3-4):246-55. DOI: 10.1016/j.vetmic.2009;08.028

11. Lundgren O, Svensson L. Pathogenesis of rotavirus diarrhea. Microbes Infect. 2001;13(3):1145-1156. DOI: 10.1016/s1286-4579(01)01475-7

12. Hagbom M, Istrate $\mathrm{C}$, Engblom $\mathrm{D}$, Karlsson $\mathrm{T}$, Rodriguez-Diaz $\mathrm{J}$, Buesa J, Taylor JA, Loitto V, Magnusson K, Ahlman H, Lundgren O, Svensson L. Rotavirus stimulates release of serotonin(5-HT) from human enterochromaffin cells and activates brain structures involved in nausea and vomiting. PLoS Pathog. 2011;7(7):e1002115.

13. Gouvea V, Glass RI, Woods P, Taniguchi K, Clark HF, Forrester B, Fang ZY. Polymerase chain reaction amplification and typing of rotavirus nucleic acid from stool specimens. J Clin Microbiol. 1990;28(2):276- 282

14. Parry J. New vaccines to Tohoolr child Care in developing countries. Bull WHO. 2017;85(6)426-7. DOI: 10.2471/BLT.07.020607

15. Fenjan MN, Jarullah BA. Molecular identification and phylogenetic analysis of rotavirus in children suffered from diarrhea under five years old in Thi-Qar Province. Iraqi J Edu Pure Sci. 2019;9(1):1=-10. DOI: 10.32792/utq.jceps.09.01.09

16. Abdulazeez AA, Abed MN. Genotyping of rotavirus in neonatal calves with acute gastroenteritis in Iraq. Advan Microbiol. 2017;7(12):863870. DOI: $10.4236 /$ aim.2017.712066

17. Yaqoob MM, Mahdi KH, Al-Hmudi HA, Ali MN. Detection of rotavirus A and Escherichia coli from diarrhea cases in children and coliphage characterization. Int $\mathrm{J}$ Curr Microbiol App Sci. 2016;2016;5(4):2319-7706. DOI: 10.20546/ijcmas.504.011

18. Senthilkumar A. study on Rotavirus gastroenteritis in children under five years in Coimbatore [PhD dissertation]. Chennai: Medical University; 2017.

19. Hassan HA, Kshash QH, Mansur KA. Detection of bovine rotavirus in diarrheic calves by using rapid test in some Mid-Euphrates provinces. Al-Qadisiya J Vet Med Sci. 2014;13. DOI: 10.29079/vol13iss2art297

20. Khalaf AS, Aldoori AA. Genomic diversity and prevalence of Rotavirus in cow and buffalo calves in middle area of Iraq. Entomol Zool Stud. 2017;5(6):1206-1211.

21. Trask SD, McDonald SM, Patton JT. Structural insights into the coupling of virion assembly and rotavirus replication. Microbiol. 2012;10(3):165-177. DOI: $10.1038 /$ nrmicro2673

22. Isihak FA. Diagnosis of reovirus infection in broiler breeder's flocks by using PCR technique in Erbil province Iraqi J Vet Sci. 2020;34(1):7781.

23. Isihak FA, Ismail HKh, Wahid AA. Diagnosis and histopathological study of avian influenza virus-H5(AIV-H5) in broiler farms. Iraqi J Vet Sci. 2020;34(1):101-107.

24. Afrad MH, Matthijnssens J, Moni S, Kabir F, Ashrafi A, Rahman MZ, Faruque ASG, Azim T, Rahman M. Genetic characterization of a rare bovine- Like human VP4 mono-reassortant G6P(8) rotavirus strain detected from an infant in Bangladesh. Infect Genet Evol 2013;19:1206. DOI: 10.1016/j.meegid.2013.06.030
25. Khalida K, Al-Kelaby A. Study on rotavirus serovars G1 and G2 isolated from acute diarrhea of children. [PhD dissertation]. Babylon: Babylon University; 2008.

26. Ahmed HM, Coulter JB, Nakagomi O, Hart CA, Zaki JM, Al-Rabaty AA, Dove W and Cunliffe NA. Molecular characterization of rotavirus gastroenteritis strains, Iraqi Kurdistan. Emerg Infect Dis. 2006;12(5):824-826. DOI: 10.3201/eid1205.051422.

27. Mehdi SG, Niazi AD, Alhamdani FG. Burden of rotavirus gastroenteritis among under five years children at Al-Alwaiya Paediatric Hospital. Iraqi Postgrad Med J. 2008;7(4):1-10.

28. Ateya, HK. Detection of rotavirus antigens and antibodies in children and bovine. [Master's thesis]. Basrah: College of Veterinary Medicine, University of Basrah; 2010.

29. Thwiny HT. Molecular detection and epidemiology of five enteric viruses (Rotavirus A, Norovirus, Sapovirus, Astrovirus and Enteric Adenovirus) among children with acute diarrhea in Basrah, Iraq. [PhD Dissertation]. Basrah: Medical college, University of Basrah; 2013.

30. Abood WS. The molecular epidemiology of rotavirus strains causing gastroenteritis in infant in the region of Mid Iraq. AL-Qadisiya $\mathbf{J}$ Vet Med Sci. 2013;1(12):1 DOI: 10.29079/vol12iss1art240

31. Ali SM, Al-Wadi GIA. Seasonal trending of rotavirus infection in infantile patients from Baghdad with acute gastroenteritis. Pharma Innovat J. 2016;5(12):37-44

32. Al-Robaiee IA, Al- Farwachi MI. Prevalence of rotaviral infection in diarrheic neonatal calves in Mosul city, Iraq. Vet World. 2013;6(8):538-540 DOI: 10.5455/vetworld.2013;538-540

33. Pourasgari F, Kaplon J, Karimi-Naghlani. Fremy C, Otarod V, AmbertBalay K, Mirjalili A, Pothier P. The molecular epidemiology of bovine rotaviruses circulating in Iran: A two-year study. Arch Virol. 2016;161(12):3483-3494. DOI: 10.1007/s00705-016-3051-0.

34. Kshash QH. Molecular detection of Rotavirus type A in diarrheic calves of Mid Euphrates governorates, Iraq. Iraqi J Vet Med. 2017;41:2. DOI: 10.30539/iraqijvm.v41i2.47

35. Abdul Aziz JM, Hama SA, Faraj HK. Molecular diagnosis and genetic relationship of foot and mouth disease virus serotype Asia1/Basne/Sul/2015. Iraqi J Vet Sci. 2019;33(1):67-73.

36. Candlan EP, Khoran FP, Hana L. Molecular identification of peste des petits ruminant's virus in wild goat and domestic small ruminants by real-time -PCR technique in Erbil-Iraq. Iraqi J Vet Sci. 2017;31(1):5154.

37. Lee SK, Choi S, Shin SH, Lee EJ, Hyun J, Kim J, Kim HS. Emergence of G8P (6) rotavirus strains in Korean neonates. Gut Pathol. 2018;10:27. DOI: 10.1186/s13099-018-0255-8

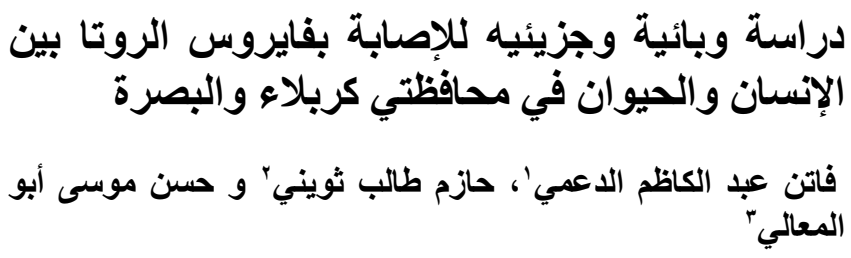

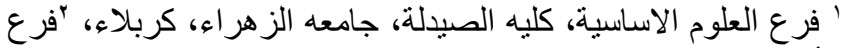

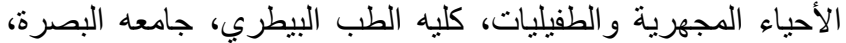

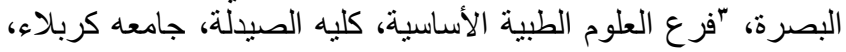
كربلاء، العراق

الخلاصة

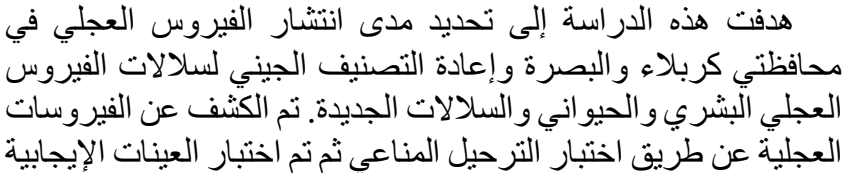




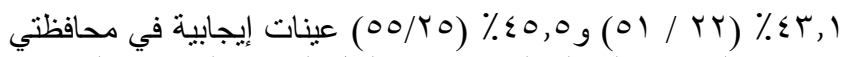

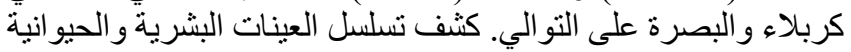

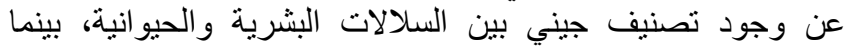

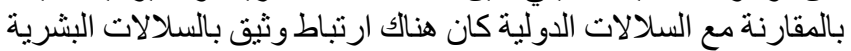

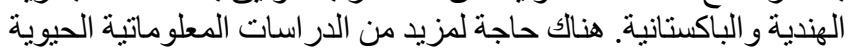

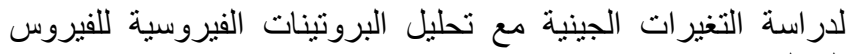

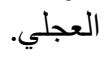

عن طريق النسخ العكسي لتفاعل البلمرة المتسلسل باستخدام بادئات

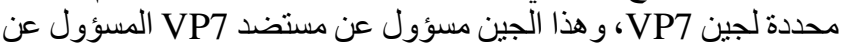

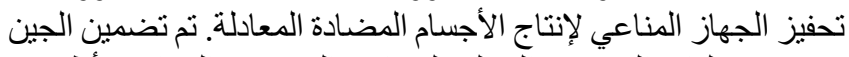

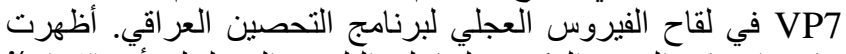

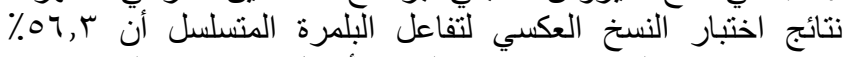
(乏N/TV)

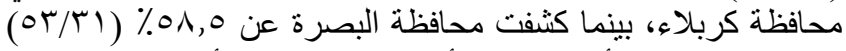
عينة موجبة عند الأطفال، بينما أظهرت العينات المأخوذة من العجول 